\title{
A new sponge-associated starfish, Astrolirus patricki sp. nov. (Asteroidea: Brisingida: Brisingidae), from the northwestern Pacific seamounts
}

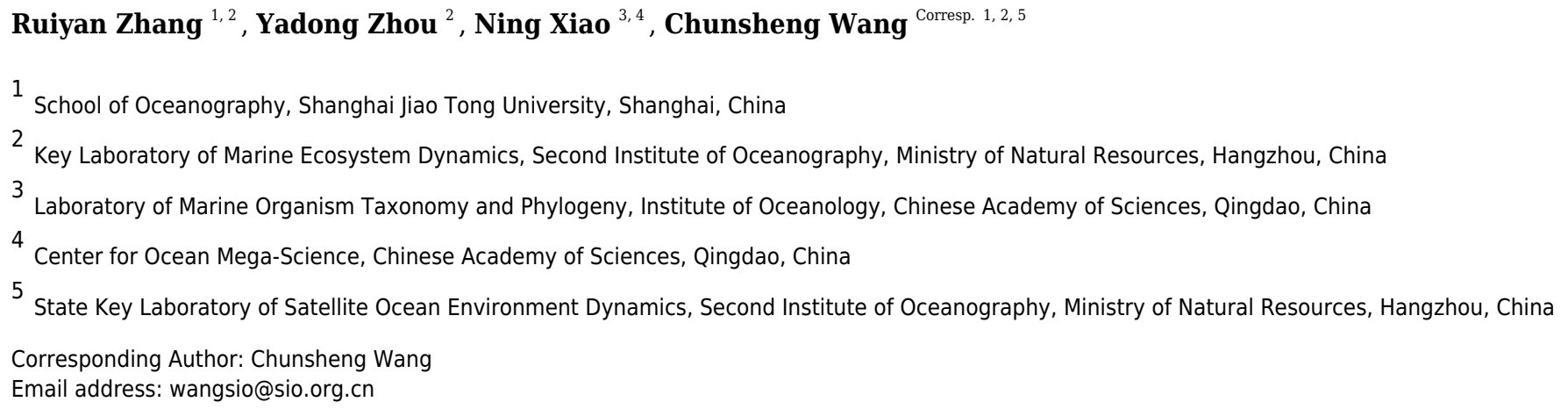

Seamounts are important deep ocean entities that serve as reservoirs for varied types of habitats and fauna. During the Chinese cruises in the northwestern Pacific seamount areas, a new starfish species of order Brisingida, Astrolirus patricki sp. nov., was found at 1458-2125 m depth. All specimens of the new species were observed in situ attaching on hexactinellid sponges, suggesting a possible close relationship between the two taxa. $A$. patricki sp. nov. is the second known species of the genus, characterized by the abutting plates in the intercostal integument, separated first pair of adambulacral plates and densely distributed proximal spines. Phylogenetic analyses were conducted for order Brisingida to incorporate the new species as well as Hymenodiscus cf. fragilis (Fisher, 1906), Freyella cf. attenuata Sladen, 1889 and two Brisinga spp. , for which we present the molecular data for the first time. Phylogenetic trees suggest a close relationship between A. patricki sp. nov. with Brisinga species rather than with Hymenodiscus species, which is inconsistent with morphological taxonomy. This study highlights the distinct morphological and ecological characters of the new species and provides new data for future investigation on Brisingida phylogeny. 
1 A new sponge-associated starfish, Astrolirus patricki sp. nov. (Asteroidea: Brisingida:

2 Brisingidae), from the northwestern Pacific seamounts

3

4 Ruiyan Zhang ${ }^{1,2}$, Yadong Zhou ${ }^{2}$, Ning Xiao ${ }^{3,4}$, Chunsheng Wang $1,2,5^{*}$

5

$6{ }^{1}$ School of Oceanography, Shanghai Jiao Tong University, Shanghai, China

$7 \quad{ }^{2}$ Key Laboratory of Marine Ecosystem Dynamics, Second Institute of Oceanography, Ministry

8 of Natural Resources, Hangzhou, China

$9{ }^{3}$ Laboratory of Marine Organism Taxonomy and Phylogeny, Institute of Oceanology, Chinese

10 Academy of Sciences, Qingdao, China

$11{ }^{4}$ Center for Ocean Mega-Science, Chinese Academy of Sciences, Qingdao, China.

125 State Key Laboratory of Satellite Ocean Environment Dynamics, Second Institute of

13 Oceanography, Ministry of Natural Resources, Hangzhou, China

15 *Corresponding Author:

16 Chunsheng Wang

17 Email address: wangsio@sio.org.cn 


\section{Abstract}

Seamounts are important deep ocean entities that serve as reservoirs for varied types of habitats and fauna. During the Chinese cruises in the northwestern Pacific seamount areas, a new starfish species of order Brisingida, Astrolirus patricki sp. nov., was found at 1458-2125 m depth. All specimens of the new species were observed in situ attaching on hexactinellid sponges, suggesting a possible close relationship between the two taxa. A. patricki sp. nov. is the second known species of the genus, characterized by the abutting plates in the intercostal integument, separated first pair of adambulacral plates and densely distributed proximal spines. Phylogenetic analyses were conducted for order Brisingida to incorporate the new species as well as Hymenodiscus cf. fragilis (Fisher, 1906), Freyella cf. attenuata Sladen, 1889 and two Brisinga spp., for which we present the molecular data for the first time. Phylogenetic trees suggest a

Hymenodiscus species, which is inconsistent with morphological taxonomy. This study highlights the distinct morphological and ecological characters of the new species and provides new data for future investigation on Brisingida phylogeny.

\section{Introduction}

Seamounts are typical deep-sea biomes in the global ocean which harbor diverse types of habitats and benthic communities (Rogers, 2018; Victorero et al., 2018). Sponges are one of the dominant benthic fauna in seamount ecosystems, playing important ecological roles by providing habitat and settlement substrate for other seamount invertebrates, such as mollusks, hydrozoans and echinoderms (McClintock et al., 2005; Bell, 2008; Chu \& Leys, 2010). Suspension-feeding brittle stars and crinoids with long and flexible arms are often observed perching on or wrapped around sponges (Hendler, 1983; Klitgaard, 1995; McClintock et al., 2005; Wuff, 2006). In this study, a new starfish species, Astrolirus patricki sp. nov., which was found attaching to deep-sea sponges, is reported based on five specimens from the northwestern Pacific seamounts.

Brisingidae species possess 7-20 spiny arms that are up to about 40 times the length of the disk radius (Downey, 1972; Downey, 1986). As exclusive deep-sea inhabitants, their long arms and spines potentially equip them to be excellent suspension feeders, stretching out and gathering food particles in the water column in the resource-diluted deep ocean (Emson and Young, 1994; Gale et al., 2013). Brisingidae is composed of 62 extant species designated in 10 genera (Mah, 2020). Genus Astrolirus Fisher, 1917 comprises only one species, Astrolirus panamensis (Ludwig 1905), which was originally designated to genus Brisinga Asbjørnsen, 1856 and later proposed as the monotype in the new genus Astrolirus, differentiated from the other genera based on the presence of intercostal plates on arms and a pair of marginal plates between the first adambulacral plates (Ludwig 1905; Fisher 1917). This type species was discovered in the eastern Pacific Ocean at 1820-2418 m depth, with 1 eight-armed specimen and 27 nine-armed 
58

59

60

61

62

63

64

65

66

67

68

69

70

71

72

73

74

75

76

77

78

79

80

81

82

83

84

85

86

87

88

89

90

91

92

93

94

95

96

97

specimens of varying size (disc diameter 6-26 mm) reported (Ludwig 1905). Thereafter, Astrolirus has seldomly been reported or investigated in the world ocean.

Astrolirus patricki sp. nov. herein described represents a new species in the genus. All five specimens of the new species are seven-armed and were captured from hexactinellid sponges (Fig. 1). Occasionally 2-3 individuals were spotted on the same sponge along with numbers of ophiuroids and crinoids. The new species differs greatly from A. panamensis in morphology characters and living habitat. In this study we present the taxonomic descriptions and illustrations of the new species, along with DNA barcoding sequences for each specimen. Phylogenetic tree for order Brisingida was constructed to incorporate the new species and new data from Hymenodiscus cf. fragilis (Fisher, 1906), Freyella cf. attenuata Sladen, 1889 and two Brisinga spp. on the basis of previous study (Zhang et al., 2019).

\section{Materials \& Methods}

\section{Sample collection and examination}

During the COMRA (China Ocean Mineral Resources R \& D Association) cruises DY31, DY37, DY41, DY56 and a seamount cruise in the northwestern Pacific Ocean seamounts from 2013 to 2019, five specimens of the new species (Table 1) were collected by mechanical arms or siphon-pumps equipped on HOV and ROVs. Specimens were photographed in situ and on board by digital cameras. Tube feet tissues were extracted from each specimen and frozen in $-80^{\circ} \mathrm{C}$ refrigerator or liquid nitrogen for later molecular experiments, while other parts of specimens were preserved in $100 \%$ ethanol for morphological examinations. Morphological identification was conducted under a stereoscopic microscope (Zeiss Axio Zoom.V16). The type specimens of the new species are deposited in the Sample Repository of Second Institute of Oceanography (RSIO), Ministry of Natural Resources, Hangzhou, Zhejiang, China. Paratype MBM286625 is deposited in the Marine Biological Museum (MBM), Institute of Oceanology of the Chinese Academy of Sciences (IOCAS), Qingdao, China.

\section{DNA extraction, sequencing and phylogenetic analysis}

DNA extraction method, primer sequences and PCR programs were as in Zhang et al. (2017) and Zhang et al. (2019). Five barcoding genes of each specimen, COI (cytochrome oxidase subregion I), $16 \mathrm{~S}$ rDNA, $18 \mathrm{~S}$ rDNA, $12 S$ rDNA and $H 3$, were acquired and the sequences were deposited in GenBank database (see Table S1 for accession numbers). K2P (Kimura 2-parameter, Kimura 1980) pairwise genetic distances were calculated for COI genes in MEGA6 (Tamura et al. 2013).

For phylogenetic analysis, sequences of Brisingida were obtained from GenBank and accession numbers were shown in Table S1. Stichaster striatus and Cosmasterias lurida from the sibling forcipulatacean clade to the Brisingida (Mah \& Foltz, 2011) were chosen as outgroup taxa. New data from A. patricki sp. nov. and four Brisingida species including Hymenodiscus cf. fragilis, Brisinga sp.1, Brisinga sp. 2 and Freyella cf. attenuata were added in the analysis on the basis of the previous study. The combining dataset includes 21 genospecies from 10 genera of the order Brisingida and 2 outgroup species. Phylogenetic analyses were conducted for the 
98

99

100

101

102

103

104

105

106

107

108

109

110

111

112

113

114

115

116

117

118

119

120

121

122

123

124

125

126

127

128

129

130

131

132

133

134

135

136

137

concatenated sequences of all 5 genes as well as for each independent gene. Models of evolution were estimated using jModelTest (Darriba, 2012) and the GTR + I + G model was selected as the best fit model. Maximum likelihood tree was constructed in raxmalGUI (Silvestro and Michalak, 2011) using GTR + I + G model with 1000 bootstrap replicates. Bayes analysis was conducted in MrBayes (Huelsenbeck \& Ronquist, 2001) using GTR + I + G model, running for 3,000,000 generations and sampled every 1,000 generation to estimate the posterior probabilities. The first 7,500 trees were discarded as burn-in. The tree topologies were observed and edited in Figtree v1.4.3.

\section{Nomenclatural acts}

The electronic version of this article in Portable Document Format (PDF) will represent a published work according to the International Commission on Zoological Nomenclature (ICZN), and hence the new names contained in the electronic version are effectively published under that Code from the electronic edition alone. This published work and the nomenclatural acts it contains have been registered in ZooBank, the online registration system for the ICZN. The ZooBank LSIDs (Life Science Identifiers) can be resolved and the associated information viewed through any standard web browser by appending the LSID to the prefix http://zoobank.org/. The LSID for this publication is: urn:lsid:zoobank.org:pub:7C8A768D-1312-498E-8352BC4116D0B0F0. The online version of this work is archived and available from the following digital repositories: PeerJ, PubMed Central and CLOCKSS.

\section{Results}

\section{Systematics}

\section{Order Brisingida Fisher, 1928}

Family Brisingidae G.O. Sars, 1875

\section{Genus Astrolirus Fisher, 1917}

Diagnosis to Genus. Intercostal integument covered by thin plates; the first pair of adambulacral plates do not touch by their interradial faces, but are separated by a pair of marginal plates; first pair of marginal plates unit closely with a large interradial plate in the interradial faces.

\section{Astrolirus patricki sp. nov.}

urn:1sid:zoobank.org:act:0F238379-CD10-4E51-A74A-0FEF055D72A5

\section{(Figs. 1-4)}

Diagnosis. Arms 7, robust. Intercostal integument densely covered by irregular, abutting plates. No syzygy between proximal arm plates. The first pair of adambulacral plates separated by a pair of marginal plates. A large interradial plate above the first marginal plates, visible from the abactinal side, covered by scattered spinelets. Mouth spines and proximal adambulacral spines robust, densely distributed. Suboral spines 3-4; subambulacral spines 1-2, proximal ones truncate, capitate. One lateral spine to each adambulacral plate, starting from about the $8^{\text {th }}$. A pair of gonads to each arm.

Etymology. The name is originated from the character "Patrick Star" in the famous cartoon "SpongeBob Squarepants", who always spends time with his best friend "SpongeBob", a benthic 
138 sponge. Since all specimens of the new species were observed in situ living on sponges (Fig. 1),

139

140

141

142

143

144

145

146

147

148

149

150

151

152

153

154

155

156

157

158

159

160

161

162

163

164

165

166

167

168

169

170

171

172

173

174

175

176

177

it was name by Patrick to reflect this curious relationship.

Material examined. Holotype, RSIOAS044 (Fig. 1A), 7 arms, of which 3 attached to the disk, others detached. $\mathrm{r}=7.5 \mathrm{~mm}$, the longest broken arm measures $153 \mathrm{~mm}$ without the missing tip. Length of genital area $35 \mathrm{~mm}$, broadest part of arm measures $7 \mathrm{~mm}$.

Paratype RSIOAS028 (Fig. 1B), 7 arms, including 3 regenerating ones, all attaching to the disk; $\mathrm{r}=7 \mathrm{~mm}$, the longest arm measures $153 \mathrm{~mm}, \mathrm{R} / \mathrm{r}=21.9$; length of genital area $36 \mathrm{~mm}$, broadest part of arm measures $9 \mathrm{~mm}$ wide. Paratype RSIOAS003 (Fig. 1C), 7 arms, all arm detached from the disk; $r=10 \mathrm{~mm}, \mathrm{R}=190-200 \mathrm{~mm}, \mathrm{R} / \mathrm{r}=19-20$; length of genital area about $50 \mathrm{~mm}$, broadest part of arm 9-10 mm, at 15-20 mm from the disk. Paratype RSIOAS052 (Fig. 1D), 7 arms, r=7.5 $\mathrm{mm}$, the longest arm measures $168 \mathrm{~mm}, \mathrm{R} / \mathrm{r}=22.4$. Paratype MBM286625 (Fig. 1E), 7 arms, $\mathrm{r}=7.5 \mathrm{~mm}, \mathrm{R}=171 \mathrm{~mm}, \mathrm{R} / \mathrm{r}=22.8$; length of genital area about $33 \mathrm{~mm}$, broadest part of arm 7.5 $\mathrm{mm}$.

Description. Arms 7. Disk radius 7-10 mm, $\mathrm{R} / \mathrm{r}=19-22.8$. Disk thick, elevated from the plane of arms (Figs. 2A-C). Abactinal surface of disk covered by small rounded plates (Fig. 2G) bearing multiple sharp, thin spinelets, with few scattered pedicellariae between and at the base of the spinelets (Figs. 2C, 2F). Madreporite body locates at the margin of the disk, elliptical with a curved rift in the center (Fig. 2C). Papulae absent.

Abactinal surface of arm within genital area densely covered by abutting plates of irregular scale forms. Pedicellariae scattered in the proximal region connecting disk and the genital area, not forming costae (Fig. 2C). Costae present within the genital area, about 30 in number; costae thin, densely located (two to each adambulacral plate), composed of raised band of pedicellariae (Figs. 2D-E). Beyond the genital area, pedicellariae forms bands wider than costae, two to each adambulacrals (Fig. 2H). A pair of gonads to each arm. Each gonad with 3-6 oval pedals (Fig. $3 \mathrm{G})$.

Adambulacral plate in proximal area subquadrate, elongated in middle and distal part of the arms (Fig. 4). Proximally the ambulacral groove almost completely concealed by adambulacral spines (Fig. 4). The first pair of adambulacral plates on adjacent arms entirely separated by a pair of marginal plates (Figs. 3C-D). No syzygy between proximal plates. The first pair of marginal plates unit closely with an interradial plate (Fig. 3D). Interradial plate large, nearly naked, extending to the abactinal side of disk (Fig. 2C). Proximally 2-3 marginal plates well-developed, present on the lateral side of the arm (Fig. 2C). The following marginal plates degrade to a line of protuberances on the side and corresponding to each adambulacral plates, bearing long lateral spine. Lateral spine present from about the $8^{\text {th }}$ adambulacral plate, one to each plate (Figs. 3F, 4). The longest measures $15-20 \mathrm{~mm}$.

Adambulacral plate armature includes: 1) 2 subambulacral spines and 1 aboral furrow spine, forming a diagonal row; the outer subambulacral spine usually the largest and most robust; 2) 1 adoral furrow spine, thinner than the aboral one (Fig. 4). The first pair of adambulacral plate bear a diagonal line of 4-5 spines, two on the surface of the plate, and 2-3 smaller ones on the distal furrow corner (Figs. 3B-D). At middle and distal part of arm, the number of subambulacral spine

Peer) reviewing PDF | (2020:01:45134:1:1:NEW 11 Mar 2020) 
178 on each adambulacral plate reduces to 1 (Fig. 4). Proximal subambulacral spines truncate form,

179

180

181

182

183

184

185

186

187

188

189

190

191

192

193

194

195

196

197

198

199

200

201

202

203

204

205

206

207

208

209

210

211

212

213

214

215

216

capitate (Fig. 3C). The furrow spines become shorter and thinner on distal plates. All adambulacral spines bear pedicellariae, leaving only the tip of the spines naked.

Mouth plate large, bearing 3-4 robust suboral spines, forming a diagonal line, similar in form with the proximal subambulacral spines (Figs. 3A-B); 2 small furrow spines present on the aboral corner of the plate, close to the first adambulacral plate; on the oral margin, the plate bears 2 very minute spines, one pointing to the actinostome and one pointing rather to the furrow, forming a sharp angle with the former. All oral spines bear pedicellariae.

Variations in paratypes. In the paratypes, adambulacral plates at middle and distal part of arm bear equal number of spines as the proximal adambulacral plates (Fig. 3F), instead of having one less subambulacral spine as in the holotype. In several undeveloped arms in the paratypes, gonads were not spotted. The shape and size of the marginal and interradial plates vary slightly in paratype RSIOAS003 (Fig. 3E).

Coloration. Color in life orange (Figs. 1, 2A-B).

Distribution. Known from the northwestern Pacific Ocean, on seamounts, 1458-2125 m depth. Molecular and phylogenetic results. $C O I \mathrm{~K} 2 \mathrm{P}$ distances between specimens of $A$. patricki sp. nov. are less than 0.003 , which are considered to be intraspecific distances. A. patricki sp. nov. is closest to Brisinga species, with distances between $0.123-0.159$. The topology of the Bayes tree is shown in Fig. 5 and the nodes marked by black dots are support by both Bayes tree and ML tree. This tree is overall in line with results of the previous studies (Mah \& Foltz, 2011; Zhang et al., 2019).

Remarks for $\boldsymbol{A}$. patricki sp. nov.. Types of $A$. patricki sp. nov. from different seamounts show little intraspecific divergences other than size and adambulacral spine number. The difference between A. patricki sp. nov. and the type species of the genus, A. panamensis, are listed in Table 2. Although both species are characterized by the presence of abactinal plates, in A. panamensis the plates locate between the transverse costae, whereas in A. patricki sp. nov. a mosaic of abutting plates forms the abactinal arm skeleton. The two species further differ in arm number, adambulacral spine number and distribution, as well as the number of genital organs. It should be noticed that, in Ludwig's original description of A. panamensis, "several, consecutive pairs of branched gonads on each arm (4-5 in one male specimen)" were recorded, each branch has their own gonopore (Ludwig, 1905), but later when Fisher established the new genus, he described Astrolirus as having 2-4 gonads to each arm (Fisher, 1917). Whether this new description resulted from a reexamination of the type specimens was not clearly indicated (Fisher, 1917). Therefore, in this study we choose to follow Ludwig's original descriptions when evaluate the differences between the new species and $A$. panamensis.

In addition, $A$. patricki sp. nov. is characterized by a large number of suboral spines (3-4), whereas in A. panamensis, only 1 suboral spine present on each oral plate. Interestingly, in $A$. panamensis, some large specimens ( $\mathrm{r}=13$ or $10.5 \mathrm{~mm}$ ) have the 2 suboral spines on a pair of oral plates covered in a same membrane (Ludwig, 1905). This characteristic has only been reported in

Peer) reviewing PDF | (2020:01:45134:1:1:NEW 11 Mar 2020) 
217 Brisinga andamanica Wood-Mason \& Alcock, 1891 and Brisinga bengalensis Wood-Mason \& 218 Alcock, 1891 (Alcock, 1893), whose biological function is not clear.

219

220

221

222

223

\section{Discussion}

The $C O I$ genetic distances $(<0.003)$ fall in the range of intraspecific distance suggested by Ward et al. (2008) for Asteroidea, which confirmed that specimens of A. patricki sp. nov. are indeed the same species. Based on the current dataset, the new species is genetically closer to

224 Brisinga species (0.123-0.159) rather than to Hymenodiscus Perrier, 1884 species (0.194-0.203).

225

226 The former distance barely falls out of the range of congeneric divergence of Asteroidea,

227 whereas the latter is an undoubted intergeneric distance (Ward et al., 2008). Similar results were also suggested by the phylogenetic analyses. In the Brisingidae clade, A. patricki sp. nov.

228

229 appears to be intermediate between the Brisinga clade and Hymenodiscus spp., forming a sister clade with Brisinga spp. and Freyellaster fecundus (Fig. 5). The molecular evidence is to some

230

231

232

233 degree inconsistent with the morphological taxonomy. Based on morphological characteristics, Hymenodiscus and Astrolirus could be differentiated from other Brisingidae genera in having the paired marginal plates between the first adambulacral plates. Hymenodiscus further differs from

234

235

236

237

238

239

240

241

242

243

244

245

246

247

248

249

250

251

252

253

254

255

Astrolirus in having bare integument between costae. Previous cladistic analysis on Brisingida phylogeny also suggest that the two genera should cluster as a derived clade (Mah, 1998a, 1998b). The reason for such a discrepancy between molecular and morphological evidence is not clear yet. In addition, several nodes in the ML tree were support with low bootstrap value (Fig. 5), possibly owing to data deficiency. Genetic data from other Brisingidae species and genera should be supplemented in the future for a comprehensive phylogenetic analysis.

\section{Conclusions}

The new species Astrolirus patricki sp. nov. reported in this study represents the second known species in the genus, which is distinguished from its congener by the form and organization of costae and intercostal plates as well as numbers of spines and arms.

Morphological description and molecular data delimitate the new species and provide reference for future taxonomic and phylogenetic study of related species. The current phylogenetic analysis on order Brisingida indicates an intermediate position of $A$. patricki sp. nov. between Brisinga and Hymenodiscus, but more samples and multi-gene analysis are needed in the future to clarify the actual systematic and phylogenetic relationships among these genera.

\section{Acknowledgements}

We thank all the scientists and crew on the R/V XIANGYANGHONG 9, R/V HAIYANGLIUHAO, $\mathrm{R} / \mathrm{V} D A Y A N G Y I H A O$ and $\mathrm{R} / \mathrm{V}$ KEXUE for their work in the collection of the specimens. Dr. Christopher Mah from Smithsonian Institution and Dr. Anna Dilman from P. P. Shirshov Institute of Oceanology are thanked for their suggestions on the examination of the new species. We also thank Dr. Dongsheng Zhang, Dr. Chengcheng Shen, Dr. Dong Sun, Dr. Bo Lu and 
256 Jieying $\mathrm{Na}$ in our lab for their helps in sampling, experiments and suggestion on the writing of 257 this paper.

258

259

260

261

262

263

264

265

266

267

268

269

270

271

272

273

274

275

276

277

278

279

280

281

282

283

284

285

286

287

288

289

290

291

292

293

294

295

\section{References}

Alcock, A. (1893). XV.- - Natural history notes from HM Indian marine survey Steamer 'Investigator,'Commander CF Oldham, RN, commanding.--Series II., No. 7. An account of the collection of deep-sea Asteroidea. Journal of Natural History, 11(62), 73-121.

Amon, D.J., Ziegler, A.F., Kremenetskaia, A., Mah, C.L., Mooi, R., O'Hara, T., Pawson, D.L., Roux, M. \& Smith, C.R. (2017). Megafauna of the UKSRL exploration contract area and eastern Clarion-Clipperton Zone in the Pacific Ocean: Echinodermata. Biodiversity data journal, (5).

Bell, J. J. (2008). The functional roles of marine sponges. Estuarine, coastal and shelf science, 79(3), 341-353.

Bell, J. J., \& Barnes, D. K. (2000). The influences of bathymetry and flow regime upon the morphology of sublittoral sponge communities. Journal of the Marine Biological Association of the United Kingdom, 80(4), 707-718.

Cerrano, C., Bavestrello, G., Calcinai, B., Cattaneo-Vietti, R., \& Sarà, A. (2000). Asteroids eating sponges from Tethys Bay, East Antarctica. Antarctic Science, 12(4), 425-426.

Chu, J. W., \& Leys, S. P. (2010). High resolution mapping of community structure in three glass sponge reefs (Porifera, Hexactinellida). Marine Ecology Progress Series, 417, 97-113.

Darriba, D., Taboada, G. L., Doallo, R., \& Posada, D. (2012). jModelTest 2: more models, new heuristics and parallel computing. Nature Methods 9(8), 772.

Downey, M. E. (1972). Midgardia xandaros new genus, new species, a large brisingid starfish from the Gulf of Mexico. Proceedings of the Biological Society of Washington, 84, 421426.

Downey, M.E. (1986). Revision of the atlantic brisingida (Echinodermata: Asteroidea), with description of a new genus and family. Smithsonian Contributions to Zoology, 435, 1-57.

Emson, R.H. \& Young, C. M. (1994). Feeding mechanism of the brisingid starfish Novodinia antillensis. Marine Biology, 118, 433-442.

Fisher, W. K. (1917). LI.- New genera and species of Brisingidae. Annals and Magazine of Natural History, Series 8, 20:120, 418-431

Gale, K. S. P., Hamel, J. F., \& Mercier, A.. (2013). Trophic ecology of deep-sea Asteroidea (Echinodermata) from eastern Canada. Deep Sea Research Part I: Oceanographic Research Papers, 80, 25-36.

Gale, K. S. P., Mah, C., Hamel, J. F. \& Mercier, A. (2014). New records of brisingidan asteroids (Asteroidea: Brisingida) in eastern Canada. Marine Biodiversity Records, 7.

Glover, A.G., Wiklund, H., Rabone, M., Amon, D.J., Smith, C.R., O'Hara, T., Mah, C.L. \& Dahlgren, T.G. (2016). Abyssal fauna of the UK-1 polymetallic nodule exploration claim, clarion-clipperton zone, central Pacific Ocean: Echinodermata. Biodiversity Data Journal, 4(4), e7251

Peer) reviewing PDF | (2020:01:45134:1:1:NEW 11 Mar 2020) 
296

297

298

299

300

301

302

303

304

305

306

307

308

309

310

311

312

313

314

315

316

317

318

319

320

321

322

323

324

325

326

327

328

329

330

331

332

333

334

Hendler, G. (1984). The Association of Ophiothrix lineata and Callyspongia vaginalis: A Brittlestar-Sponge Cleaning Symbiosis?. Marine Ecology, 5(1), 9-27.

Huelsenbeck, J. P., \& Ronquist, F. (2001). MRBAYES: Bayesian inference of phylogenetic trees. Bioinformatics, 17(8), 754-755.

Kimura, M. (1980) A simple method of estimating evolutionary rate of base substitutions through comparative studies of nucleotide sequences. Journal of Molecular Evolution, 16, $111-120$.

Klitgaard, A. B. (1995). The fauna associated with outer shelf and upper slope sponges (Porifera, Demospongiae) at the Faroe Islands, northeastern Atlantic. Sarsia, 80(1), 1-22.

Ludwig, H. (1905). Asteroidea. Memoirs of the Museum of Comparative Zoology at Harvard, 32, 97-100. [in Germany].

Mah, C. (1998a). Preliminary phylogeny and taxonomic revision of the Brisingida. pp. 273-277 in: Mooi, R.; Telford, M. (eds), Proceedings of the Ninth Echinoderm Conference, San Francisco, 1996. A.A. Balkema, Rotterdam.

Mah, C. L. (1998b). A phylogeny, taxonomic revision, and natural history of the order Brisingida (Asteroidea). Unpublished Master's Thesis, San Francisco State University.

Mah, C. L. (2016). A new species of Brisingenes from the Hawaii undersea military munitions assessment area with an overview of Hawaiian brisingid in situ video observations and functional morphology of subambulacral spines (Forcipulatacea; Asteroidea). Deep Sea Research Part II: Topical Studies in Oceanography, 128, 43-52.

Mah, C. \& Foltz, D. (2011). Molecular phylogeny of the Forcipulatacea (Asteroidea: Echinodermata): systematics and biogeography. Zoological Journal of the Linnean Society, 162(3), 646-660.

Mah, C. L. (2020). World Asteroidea Database. Brisingidae G.O. Sars, 1875. Accessed through: World Register of Marine Species at: http://www.marinespecies.org/aphia.php? $\mathrm{p}=$ taxdetails \&id=123119

McClintock, J. B. (1994). Trophic biology of Antarctic shallow-water echinoderms. Marine ecology progress series. Oldendorf, 111(1), 191-202.

McClintock, J. B., Amsler, C. D., Baker, B. J., \& Van Soest, R. W. (2005). Ecology of Antarctic marine sponges: an overview. Integrative and Comparative Biology, 45(2), 359-368.

Reiswig, H. M. (1971). In situ pumping activities of tropical Demospongiae. Marine Biology, 9(1), 38-50.

Rogers, A. D. (2018). The biology of seamounts: 25 years on. In Advances in marine biology (Vol. 79, pp. 137-224). Academic Press.

Silvestro, D. \& Michalak, I., (2012). Raxmlgui: a graphical front-end for raxml. Organisms Diversity \& Evolution, 12 (4), 335-337.

Tamura, K., Stecher, G., Peterson, D., Filipski, A. \& Kumar, S. (2013) Mega6: molecular evolutionary genetics analysis version 6.0. Molecular Biology \& Evolution, 30 (12), 27252729. 
335 Victorero, L., Robert, K., Robinson, L. F., Taylor, M. L., \& Huvenne, V. A. (2018). Species 336 replacement dominates megabenthos beta diversity in a remote seamount setting. Scientific 337 reports, $8(1), 4152$.

338 Ward, R.D., Holmes, B.H. \& O'Hara, T.D. (2008) DNA barcoding discriminates echinoderm 339 species. Molecular Ecology Resources, 8 (6), 1202-1211.

340 Wulff, L. (1995). Sponge-feeding by the Caribbean starfish Oreaster reticulatus. Marine Biology, $341 \quad 123(2), 313-325$.

342 Wulff, J. L. (2006). Ecological interactions of marine sponges. Canadian Journal of Zoology, 343 84(2), 146-166.

344 Zhang, R., Zhou, Y., Lu, B. \& Wang, C. (2017). A new species in the genus Styracaster

345 (Echinodermata: Asteroidea: Porcellanasteridae) from hadal depth of the Yap Trench in the $346 \quad$ western Pacific. Zootaxa, 4338(1), 153-162.

347 Zhang, R., Wang, C., Zhou, Y., \& Zhang, H. (2019). Morphology and molecular phylogeny of two new species in genus Freyastera (Asteroidea: Brisingida: Freyellidae), with a revised key to close species and ecological remarks. Deep Sea Research Part I: Oceanographic Research Papers, 154, 103163. 
Figure 1

In situ photographs of Astrolirus patricki sp. nov.

(A) Holotype RSIOAS044. (B) Paratype RSIOAS028. (C) Paratype RSIOAS003. (D) Paratype RSIOAS052. (E) Paratype MBM286625.
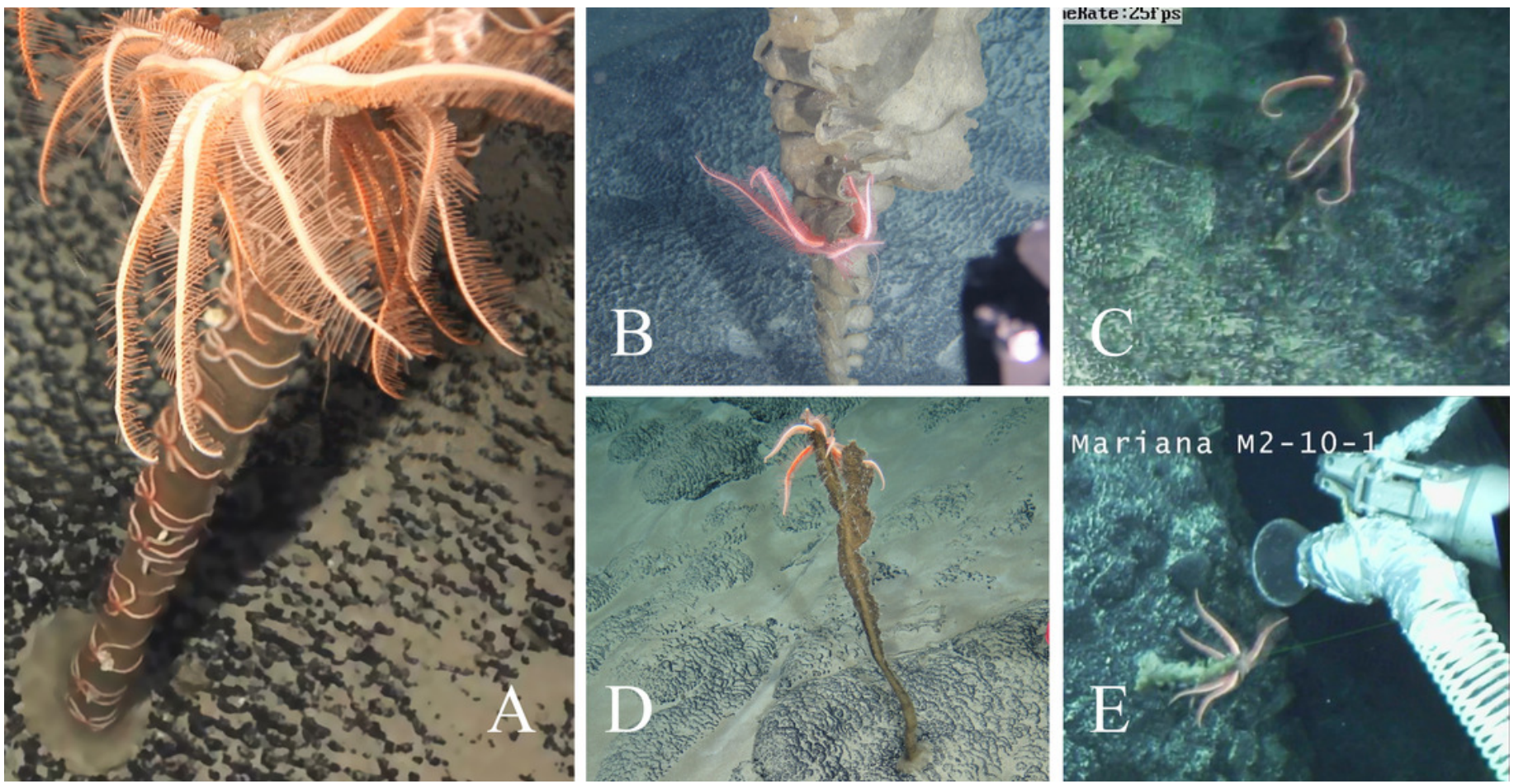


\section{Figure 2}

Astrolirus patricki sp. nov. , abactinal view.

(A) Paratype RSIOAS028. (B) Paratype RSIOAS003. (C), (D), (H), holotype RSIOAS044, (C) Abactinal surface of disk and proximal part of arms, with red arrow pointing at the madreporite body, white arrow at the interradial plate and yellow arrows at the marginal plates. The red frame indicates the proximal region of arm connecting the disk and genital region, where pedicellariae do no form regular costae . (D) Abactinal surface of arm genital area with mosaic plating, red arrows show the costae bands. (E) Paratype RSIOAS003, abactinal surface of arm genital area, red arrows show the costae bands. (F) Paratype RSIOAS052, zoom in view of the abactinal disk, showing the multiple sharp spinelets on disk plates. (G) Paratype RSIOAS052, a piece of dissected skin from abactinal disk, shot from the inner side of the skin, showing the small round disk plates. $(\mathrm{H})$ Abactinal surface at the middle of arm, black arrows indicate the pedicellariae bands. 


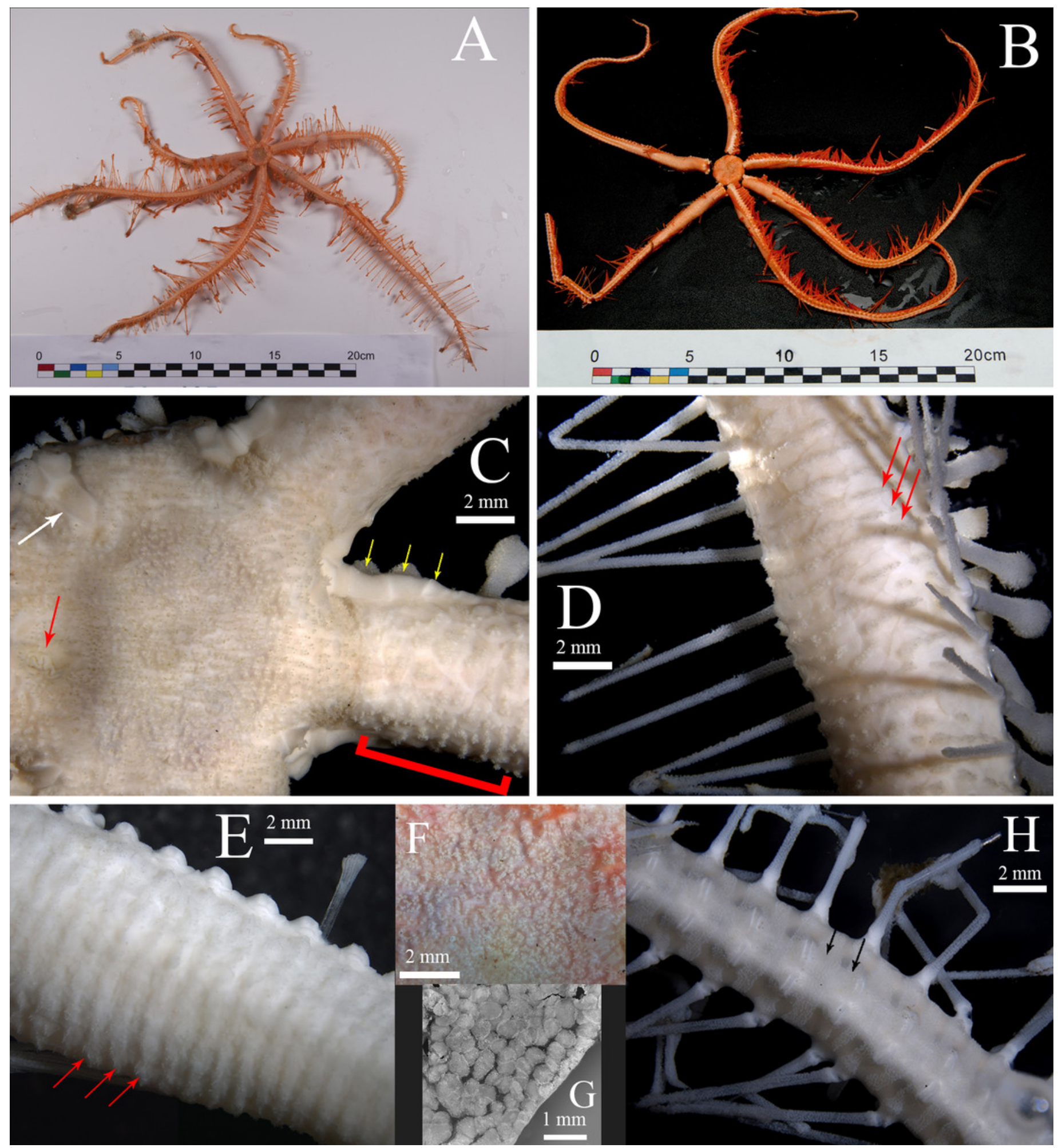




\section{Figure 3}

Astrolirus patricki sp. nov. actinal view.

(A)-(D), (G), holotype RSIOAS044. (A) Actinal surface of the disk. (B) oral plates and spines;

(C) Interradial angle between arms, red arrow shows the first marginal plates, yellow arrow shows the second marginal plate. (D) Lateral view of the disk, showing the conjunction of plates in the interradii. Red arrows show the first marginal plates, yellow arrows show the first adambulacral plates, white arrow shoes the interradial plate. (E) Paratype RSIOAS003, lateral view of the disk, red arrows show the first marginal plates, yellow arrows show the first adambulacral plates, white arrow shoes the interradial plate . (F) Paratype RSIOAS052, adambulacral plates and spines at the middle of arm, yellow arrows show the subambulacral spines, white arrows show the furrow spines, red arrows show the lateral spines. (G) One of the paired gonads and digestive caeca in genital area. 

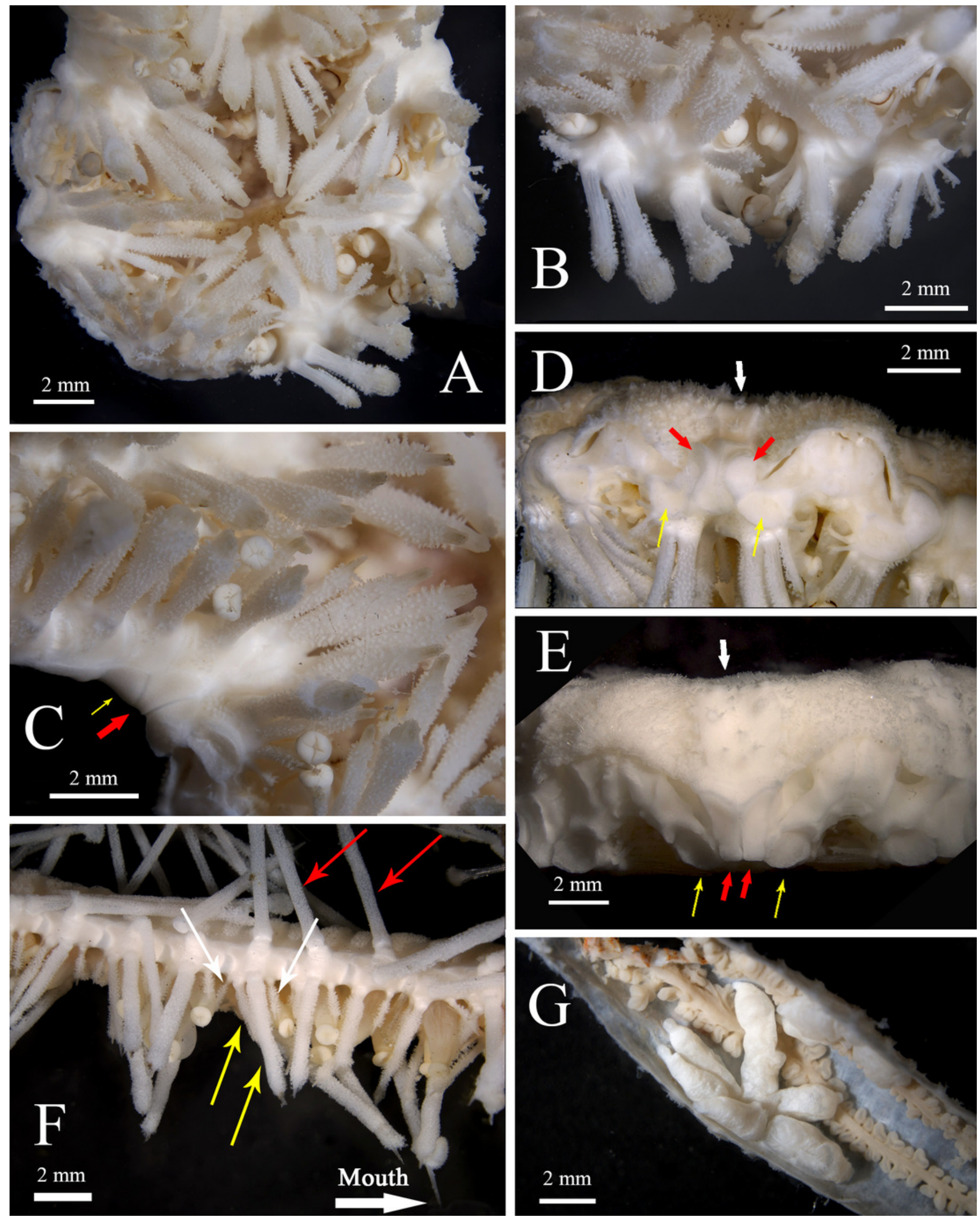


\section{Figure 4}

Astrolirus patricki sp. nov. holotype RSIOAS044, mosaic image of abactinal arm.

Yellow arrows show the subambulacral spines, white arrow shows the aboral furrow spine, black arrow shows the adoral furrow spine, red arrows show the lateral spines.

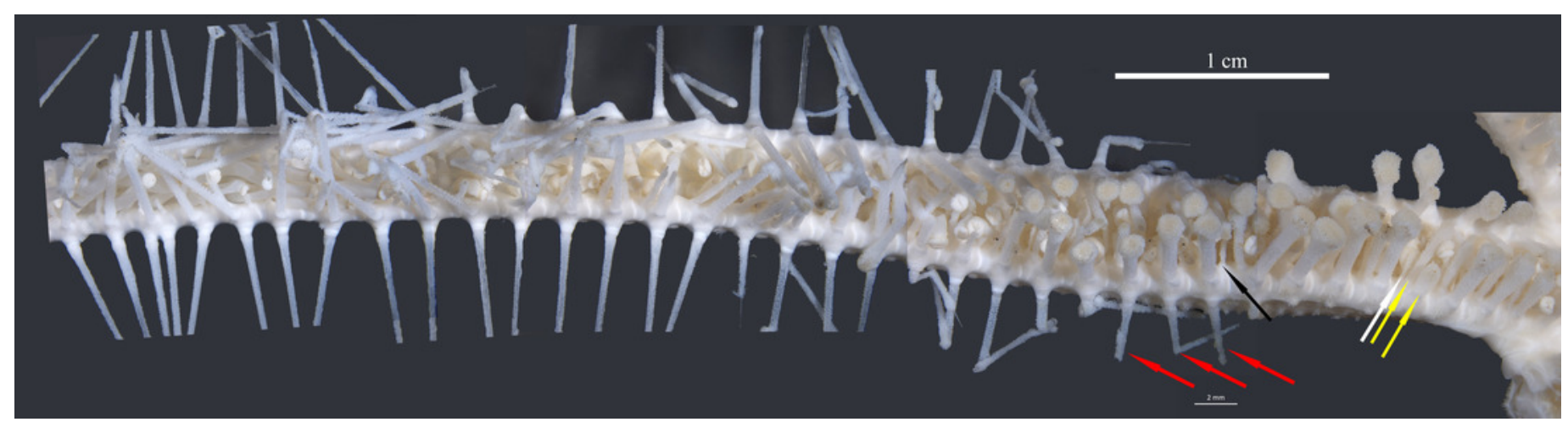


Figure 5

Phylogenetic tree of order Brisingida including Astrolirus patricki sp. nov. and 4 new specimens based on a concatenated dataset of $\mathrm{COI}, 16 \mathrm{~S}, \mathrm{H3}, 12 \mathrm{~s}$ and $18 \mathrm{~s}$ genes.

Topology follows the result of Bayes tree, bootstrap values and posterior probability are shown for each node. Nodes marked by black dots are support by both Maximum Likelihood Tree and Bayes Tree. The new species and new data reported in this study are colored red in the tree.

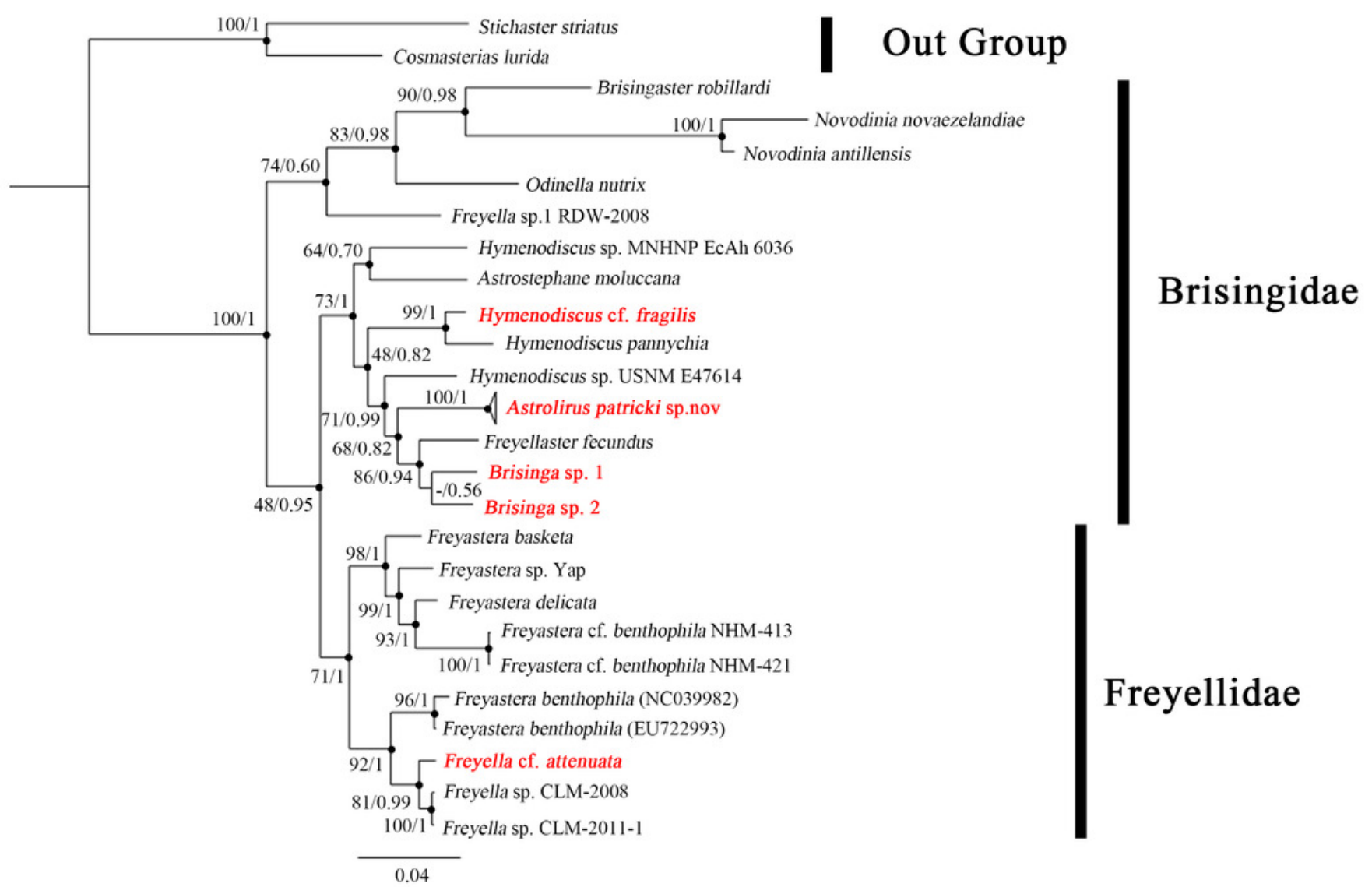




\section{Table $\mathbf{1}$ (on next page)}

Sampling information of Astrolirus patricki sp. nov. and four Brisingida specimens reported in this study. 
Table 1. Sampling information of Astrolirus patricki sp. nov. and four Brisingida specimens reported in this study.

\begin{tabular}{|c|c|c|c|c|c|}
\hline Species & $\begin{array}{l}\text { Specimen } \\
\text { voucher }\end{array}$ & Cruise and station & Collection Site & Depth (m) & Collection Date \\
\hline \multirow{5}{*}{$\begin{array}{l}\text { Astrolirus } \\
\text { patricki sp. } \\
\text { nov. }\end{array}$} & $\begin{array}{l}\text { holotype, } \\
\text { RSIOAS044 }\end{array}$ & $\begin{array}{l}\text { DY41B, } \\
\text { MCROV06 }\end{array}$ & $\begin{array}{l}\text { Weijia Seamount, northwestern } \\
\text { Pacific Ocean, } 156.41^{\circ} \mathrm{E}, 12.47^{\circ} \mathrm{N}\end{array}$ & 1935 & 2017.9 .21 \\
\hline & $\begin{array}{l}\text { paratype, } \\
\text { RSIOAS028 }\end{array}$ & DY37-I, Dive105 & $\begin{array}{l}\text { Weijia Seamount, northwestern } \\
\text { Pacific Ocean, } 156.78^{\circ} \mathrm{E}, 12.96^{\circ} \mathrm{N}\end{array}$ & 1581 & 2016.4.30 \\
\hline & $\begin{array}{l}\text { paratype, } \\
\text { RSIOAS003 }\end{array}$ & DY31-III, Dive73 & $\begin{array}{l}\text { Caiqi Seamount, northwestern } \\
\text { Pacific Ocean, } 154.98^{\circ} \mathrm{E}, 15.22^{\circ} \mathrm{N}\end{array}$ & 1807 & 2013.9 .9 \\
\hline & $\begin{array}{l}\text { paratype, } \\
\text { RSIOAS052 }\end{array}$ & DY56, ROV12 & $\begin{array}{l}\text { RD Seamount, northwestern } \\
\text { Pacific Ocean, } 149.85^{\circ} \mathrm{E}, 13.36^{\circ} \mathrm{N}\end{array}$ & 2125 & 2019.10 .10 \\
\hline & $\begin{array}{l}\text { paratype, } \\
\text { MBM286625 }\end{array}$ & FX-Dive70 & $\begin{array}{l}\text { M2 seamount near the Mariana } \\
\text { Trench, northwestern Pacific } \\
\text { Ocean, } 139.42^{\circ} \mathrm{E}, 11.27^{\circ} \mathrm{N}\end{array}$ & 1458 & 2016.3.27 \\
\hline Brisinga sp.1 & RSIOAS007 & DY35-I, Dive83 & $\begin{array}{l}\text { Lamont Seamount, northwestern } \\
\text { Pacific Ocean, } 159.25^{\circ} \mathrm{E}, 21.61^{\circ} \mathrm{N}\end{array}$ & 1773 & 2014.7 .29 \\
\hline Brisinga $\mathrm{sp} .2$ & RSIOAS023 & DY31-III, Dive70 & $\begin{array}{l}\text { Caiwei Seamount, northwestern } \\
\text { Pacific Ocean, } 155.55^{\circ} \mathrm{E}, 15.93^{\circ} \mathrm{N}\end{array}$ & 2431 & 2013.9.4 \\
\hline $\begin{array}{l}\text { Hymenodiscus } \\
\text { cf. fragilis }\end{array}$ & RSIOAS009 & DY37-I, Dive104 & $\begin{array}{l}\text { Weijia Seamount, northwestern } \\
\text { Pacific Ocean, } 156.51^{\circ} \mathrm{E}, 12.65^{\circ} \mathrm{N}\end{array}$ & 1957 & 2016.4.28 \\
\hline $\begin{array}{l}\text { Freyella cf. } \\
\text { attenuata }\end{array}$ & RSIOAS037 & $\begin{array}{l}\text { DY38-III, } \\
\text { Dive143 }\end{array}$ & $\begin{array}{l}\text { Mariana Trench, northwestern } \\
\text { Pacific Ocean, } 141.97^{\circ} \mathrm{E}, 11.82^{\circ} \mathrm{N}\end{array}$ & 4783 & 2017.5.23 \\
\hline
\end{tabular}




\section{Table 2 (on next page)}

Major morphological differences between $A$. patricki sp. nov. and A. panamansis. 
1 Table 2. Major morphological differences between $A$. patricki sp. nov. and $A$. panamansis.

\begin{tabular}{|c|c|c|}
\hline Diagnostic characteristics & A. patricki sp. nov. & A. panamansis \\
\hline arm number & 7 & $8-9$ \\
\hline costae & raised bands of pedicellariae & a transverse line of up to 11 strong, thick plates \\
\hline intercostal plates & abutting & usually isolated by small distances \\
\hline adambulacral plate armature & $\begin{array}{l}1-2 \text { subambulacral spines, } 1 \text { adoral } \\
\text { and } 1 \text { aboral furrow spines }\end{array}$ & $\begin{array}{l}1 \text { subambulacral spine, } 1 \text { adoral and } 1 \text { aboral } \\
\text { furrow spines in most specimen }\end{array}$ \\
\hline lateral spines & 1 to each adambulacral plate & $\begin{array}{l}\text { on every second or third adambulacral plate (in } \\
\text { irregular change) }\end{array}$ \\
\hline suboral spine & $3-4$ & 1 \\
\hline genital organ & 1 pair to each arm & $\begin{array}{l}\text { several, consecutive pairs on each arm ( } 4-5 \text { in } \\
\text { one male specimen) }\end{array}$ \\
\hline
\end{tabular}

